\title{
PENGARUH VARIASI ARUS PENGELASAN TIG (TUNGSTEN INERT GAS) TERHADAP SIFAT FISIK DAN MEKANIK PADA STAINLESS STEEL HOLLOW 304
}

\author{
Mohamad Lasno*, Helmy Purwanto dan Muhammad Dzulfikar \\ Jurusan Teknik Mesin, Fakultas Teknik, Universitas Wahid Hasyim \\ Jl. Menoreh Tengah X/22, Sampangan, Semarang 50236, Indonesia \\ *Email: Mohamad.Lasno16@gmail.com
}

\begin{abstract}
Abstrak
Penggunaan stainless steel dalam bidang rekayasa konstruksi baja berkembang sangat signifikan. Hal ini karena stainless steel memiliki beberapa keunggulan dalam penerapannya, seperti sifat tahan korosinya yang tinggi. Salah satu proses penyambungan yang biasa dilakukan pada stainless steel adalah dengan pengelasan TIG (Tungsten Inert Gas). Pemilihan kuat arus yang tepat dalam pengelasan TIG sangat berpengaruh terhadap sifat fisik dan mekanik hasil pengelasan. Penelitian ini bertujuan untuk mengetahui pengaruh variasi arus listrik terhadap struktur makro dan mikro, uji tarik serta distribusi kekerasannya. Material stainless steel hollow 304 berukuran $40 \times 40 \times 1,5$ mm, elektroda tungsten Weldcraft AWS EWTH-2 dan kawat las Nikko Steel NSN-308LR berdiameter 1,6 mm dengan variasi arus pengelasan 60 A, 70 A, 80 A, 90 A dan 100 A. Hasil foto makro dan struktur mikro menunjukkan pengelasan yang paling bagus terdapat pada arus 100 A, karena permukaan hasil lasnya terlihat tidak bersekat dan penetrasinya dalam. Struktur mikro pada daerah las juga halus dan rapat, didominasi fasa austenite serta terdapat kandungan karbida krom. Hasil pengujian tarik paling tinggi 608,95 MPa terletak pada arus 100 A, dan kekuatan tarik terendah terdapat pada penggunaan arus 60 A dengan nilai 438,97 MPa. Distribusi kekerasan paling tinggi di daerah las adalah 88 HRB terletak pada pengelasan arus 100 A dan paling rendah 84,25 HRB pada arus 80 A. Sedangkan nilai kekerasan tertinggi pada daerah HAZ sebesar 72,75 HRB pada arus 60 A dan nilai kekerasan paling rendah pada arus 100 A dengan nilai 60,75 HRB. Ini menandakan bahwa panas yang masuk saat pengelasan dapat memperbesar butir sehingga struktur logamnya menjadi kasar. Dimana kekasaran struktur logam pada suatu material dapat menurunkan kekuatan mekanisnya.
\end{abstract}

Kata kunci: Arus las, hollow 304, stainless steel dan TIG

\section{PENDAHULUAN}

Kemajuan rekayasa konstruksi baja dalam bidang perancangan konstruksi rumah tangga, mesin dan bangunan perkembangannya semakin pesat. Penggunaan material baja tahan karat (stainless steel) sangat tepat digunakan dalam industri rekayasa konstruksi baja, karena stainless steel memiliki beberapa keunggulan seperti tahan pada suhu tinggi, kuat, ringan, ketahan korosi yang tinggi serta tampilannya yang menarik (berseri).

Dalam hal rekayasa konstruksi baja tentunya berkaitan erat dengan proses pengelasan, karena pengelasan sangat berpengaruh terhadap mutu dan kualitas dari desain produk. Pengelasan adalah penyambungan dua buah logam berbeda dengan cara memanaskan atau menekan, yang kemudian menyambung dan menjadi satu seperti benda utuh (Alip, 1989).

Salah satu metode pengelasan yang sering digunakan dalam proses penyambungan stainless steel adalah pengelasan TIG (Tungsten
Inert Gas). Las TIG atau las argon adalah jenis pengelasan busur listrik yang menggunakan elektroda tak terumpan. Elektroda tungsten hanya berfungsi sebagai penghasil nyala listrik saat bersentuhan dengan benda kerja.

Pemilihan kuat arus yang tepat dalam pengelasan sangat berpengaruh terhadap kualitas sambungan las. Penggunaan arus yang besar dapat mempengaruhi struktur atom di daerah pengelasan. Panas yang masuk saat proses pengelasan dapat memperbesar butir (pemuaian) dan struktur logam akan berubah menjadi kasar, dimana struktur logam yang kasar dapat menurunkan sifat mekanik suatu material (Sonawan, 2004).

Semakin tinggi dan optimal panas yang dihasilkan saat proses pengelasan maka akan semakin baik untuk melelehkan/mencairkan kawat las dan elektroda tungsten dengan logam induk (Widyatmoko dkk, 2017). Semakin besar kuat arus listrik yang digunakan saat proses pengelasan, maka akan semakin keras pula daerah lasannya. Hal ini disebabkan karena 
adanya pengaruh panas (heat input) yang terjadi pada logam lasan saat proses pengelasan (Widodo, 2016).

Baja tahan karat (stainless steel) merupakan material baja dengan paduan tinggi, yang kualitas sambungannya akan menjadi getas karena pengaruh panas dari proses pengelasan (Yunus dan Nofri, 2013).

Penelitian ini bertujuan untuk mengetahui perbedaan karakteristik sifat fisik dan mekanik material stainless steel hollow 304 setelah dilakukan pengelasan TIG dengan variasi arus $60 \mathrm{~A}, 70 \mathrm{~A}, 80,90 \mathrm{~A}, 100 \mathrm{~A}$ dengan pengujian foto makro, struktur mikro, uji tarik dan kekerasan.

\section{METODE PENELITIAN}

Diagram alir atau prosedur pada penelitian ini ditunjukkan pada Gambar 1.

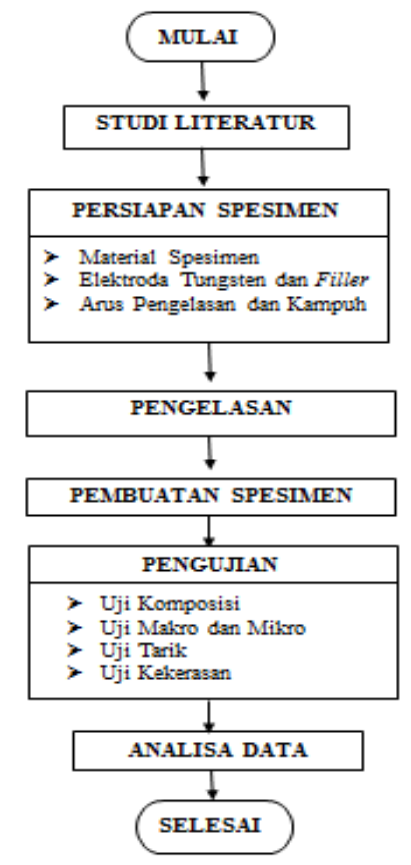

\section{Gambar 1. Diagram alir penelitian}

Alat serta bahan yang digunakan dalam penelitian ini adalah sebagai berikut:

- Mesin Las TIG arus DC Lakoni Inverter Welding tipe HAWK TIG 200e.

- Alat perkakas dan meja bangku.

- Bahan stainless steel hollow 304 ukuran 40 $\mathrm{x} 40$ x $1,5 \mathrm{~mm}$.

- Elektroda tungsten Weldcraft AWS EWTH2 diameter 1,6 mm

- Kawat las argon (Filler) Nikko Steel NSN308LR TIG diameter 1,6 mm
Prosedur dalam penelitian ini adalah melakukan studi literatur terlebih dahulu untuk menentukan bahan penelitian serta parameter pengelasannya, bahan yang digunakan stainless steel hollow 304 untuk kemudian dilakukan uji komposisi. Proses pengelasan menggunakan jenis pengelasan TIG (Tungsten Inert Gas). Hasil pengelasan TIG stainless steel hollow 304 ditunjukkan oleh Gambar 2.

Pembuatan spesimen uji tarik mengacu pada standart ASTM E8/E8M-09. Setelah itu dilakukan pengujian foto makro, struktur mikro, uji tarik dan pengujian kekerasan.

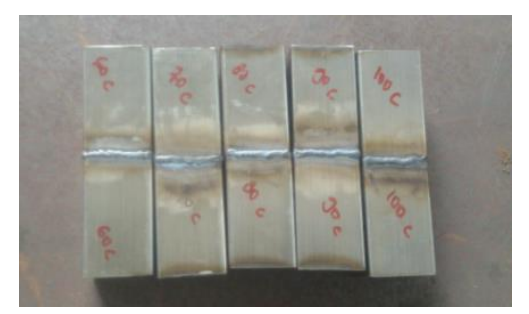

Gambar 2. Material hasil las TIG

\section{HASIL DAN PEMBAHASAN Hasil Uji Komposisi Material}

Tabel 1. Komposisi kimia stainless steel hollow 304.

\begin{tabular}{cccc}
\hline Unsur & $\begin{array}{c}\text { Presentase } \\
(\boldsymbol{\%})\end{array}$ & Unsur & $\begin{array}{c}\text { Presentase } \\
(\boldsymbol{\%})\end{array}$ \\
\hline $\mathrm{Fe}$ & Balance & $\mathrm{Mn}$ & 0,92 \\
$\mathrm{C}$ & 0,05 & $\mathrm{~V}$ & 0,12 \\
$\mathrm{Cr}$ & 17,96 & $\mathrm{Co}$ & 0,23 \\
$\mathrm{Ni}$ & 8,94 & & \\
\hline
\end{tabular}

Sumber: PT. Itokoh Ceperindo

Material stainless steel hollow 304 memiliki kandungan karbon (C) 0,05\%, dimana karbon mempunyai sifat keras, namun adanya karbon yang besar dapat menurunkan sifat ulet dan kemampuan tempa. Kandungan krom (Cr) $17 \%$ mampu meningkatkan sifat ulet, plastis dan pengaruh kondisi lingkungan, seperti korosi dan suhu tinggi. Unsur Nickel (Ni) 8,94\% berfungsi untuk meningkatkan ketahanan korosi serta membuat tampilan terlihat menarik (bercahaya seri). Unsur vanadium (V) berfungsi sebagai pembentuk karbida yang keras, sehingga material baja memiliki sifat yang sangat keras. Kandungan kobalt (Co) berguna untuk meningkatkan ketahanan aus.

\section{Hasil Foto Makro}


Foto makro dilakukan untuk melihat gambar makro dari bentuk permukaan dan penetrasi sambungan las dari spesimen benda uji. Hasil foto makro pengelasan stainless steel hollow 304 ditunjukkan Gambar 3.

Hasil dari foto makro pada Gambar 3 menunjukkan bahwa permukaan sambungan las yang paling bagus adalah pada pengelasan dengan arus 100 A (Gambar 3.e), ini dikarenakan pada arus 100 A terlihat hasil sambungan lasnya rapi dan tipis. Ini karena kawat las dan elektroda tungsten mencair sempurna. Pencairan kawat las dan elektroda yang baik ditandai dengan minimnya sekat/garis dan jauhnya jarak antar sekat. Sedangkan pada arus $60 \mathrm{~A}$ (Gambar 3.a) permukaan sambungan lasnya tidak begitu baik, karena sambungan lasnya terlihat kasar, bulat dan tebal. Hal ini dipengaruhi oleh penggunaan arus yang terlalu kecil sehingga tidak dapat mencairkan kawat las dan elektroda tungsten secara sempurna.
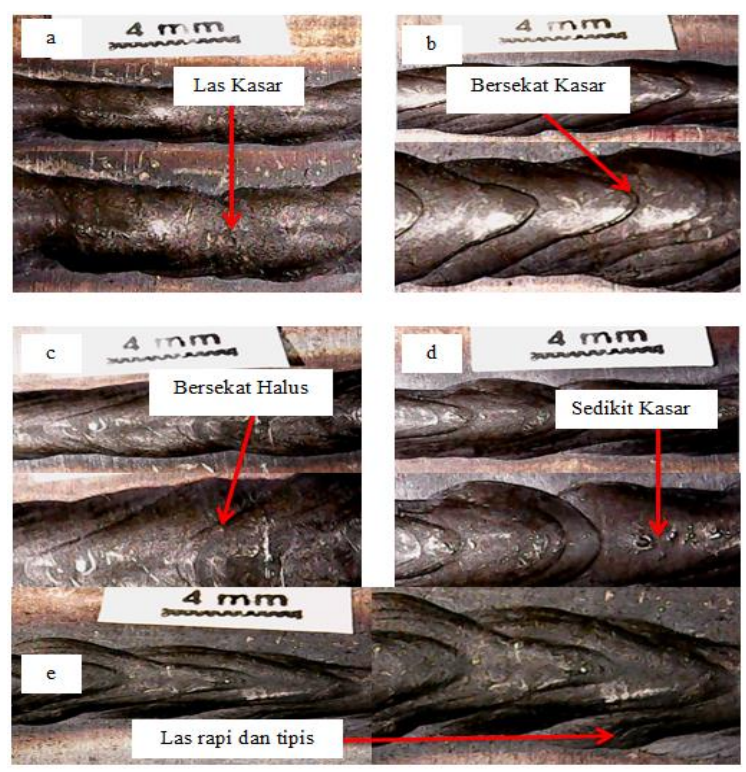

\section{Gambar 3. Hasil foto makro sambungan las arus, (a) $60 \mathrm{~A}$, (b) $70 \mathrm{~A}$, (c) $80 \mathrm{~A}$, (d) $90 \mathrm{~A}$ dan (e) $100 \mathrm{~A}$}

Pada arus 70 A dan 80 A (Gambar 3.b dan Gambar 3.c) permukaan sambungan lasnya terlihat kasar, karena masih banyak terlihat garis/sekat pada sambungan lasnya. Hal ini karena pencairan kawat las pada logam induk yang kurang sempurna. Namun pada arus $70 \mathrm{~A}$ terlihat bentuk antar garis/sekatnya lebih kasar. Penggunaan Arus 90 A (Gambar 3.d) menunjukkan permukaan sambungan lasnya rapi dan tipis, namun lasnya masih terlihat kasar dan sedikit bergaris. Semua perbedaan yang terjadi dalam permukaan sambungan las tersebut dipengaruhi oleh besar-kecilnya kuat arus dan kecepatan yang digunakan saat proses pengelasan berlangsung.

Selain melakukan pengamatan makro pada permukaan sambungan las, dilakukan juga pengamatan makro pada sambungan las setelah dilakukan proses etsa. Hasil pengamatan makro setelah dilakukan proses etsa terlihat pada Gambar 4.
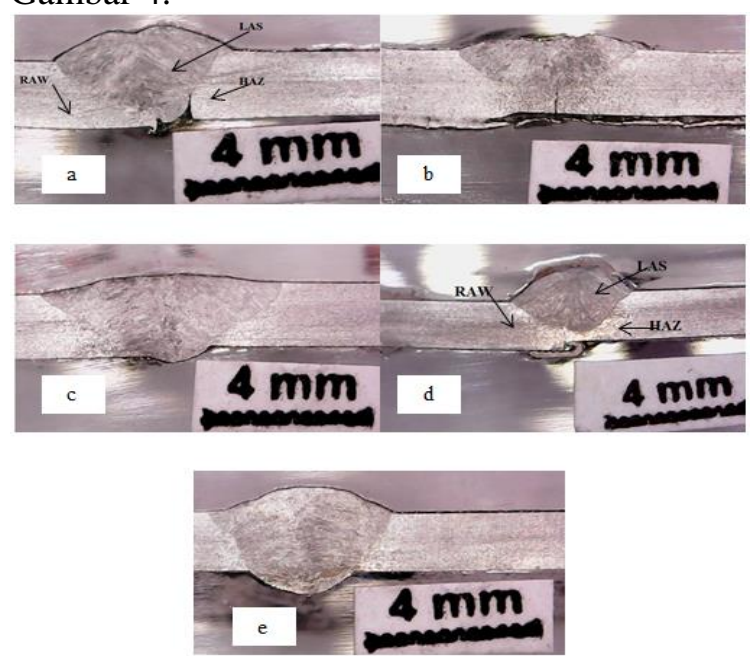

Gambar 4. Hasil foto makro setelah proses etsa, (a) $60 \mathrm{~A}$, (b) $70 \mathrm{~A}$, (c) $80 \mathrm{~A}$, (d) $90 \mathrm{~A}$ dan (e) $100 \mathrm{~A}$.

Gambar 4. menunjukkan perbedaan bentuk sambungan las dan penetrasi ke dalam daerah sambungan lasnya. Pada Gambar 4 terlihat bahwa sambungan las yang paling bagus adalah pada penggunaan arus $80 \mathrm{~A}$ (Gambar 4.c) dan 100 A (Gambar 4.e), terlihat bahan tambahan dapat tembus seluruhnya ke dalam kampuh dan menyatu dengan sempurna pada logam induk. Namun pada penggunaan arus 100 A penetrasi las lebih dalam ke lubang kampuh karena terlihat sambungan las di bagian akar lebih menonjol.

Pada arus 60 A (Gambar 4.a) terlihat penetrasi sambungan lasnya kurang sempurna atau lasnya tidak sepenuhnya menembus dan memenuhi kampuh las. Sedangkan pada penggunaan arus $70 \mathrm{~A}$ (Gambar 4.b) dan $90 \mathrm{~A}$ (Gambar 4.d) sambungan lasnya tidak begitu baik. Karena pada sambungan tersebut terlihat isian lasnya tidak sepenuhnya masuk ke dalam kampuh las, sehingga terjadi adanya cacat pengelasan (incomplete penetration). Cacat las tersebut terjadi karena bahan tambahan yang 
digunakan tidak mencair secara sempurna dan jarak kampuh yang terlalu dekat, sehingga penetrasi kurang dalam dan sulit menyatu dengan logam induk.

\section{Hasil Struktur Mikro Raw Material}

Gambar 5 menunjukkan hasil pengujian struktur mikro pada raw material, dimana struktur mikro pada raw material terlihat jelas adanya dua fase, yaitu fase Austenite dan ferit. Ferit pada struktur mikro berwarna hitam dan bersifat keras, sedangkan Austenite terlihat strukturnya berwarna putih terang dan bersifat lunak serta ulet (dimana pada Gambar 5 terlihat sangat mendominasi). Austenite lebih mendominasi karena sifat dasar logam induk yang merupakan jenis fase Austenitic yang tidak mengandung magnet (non magnetic).
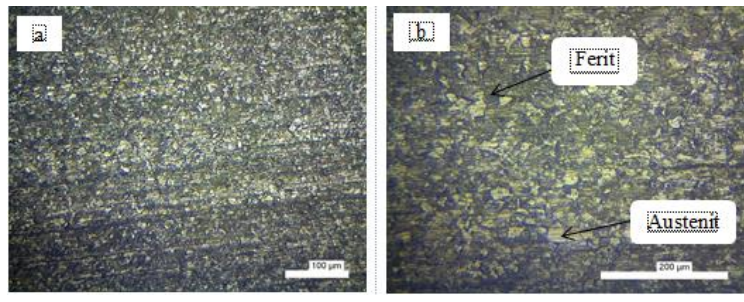

\section{Gambar 5. Hasil foto mikro raw material, (a)} perbesaran $100 \mathrm{x}$, (b) perbesaran $200 \mathrm{x}$.

\section{Hasil Struktur Mikro pada daerah Las dan HAZ}

Tabel 2 menunjukkan perbedaan hasil pengujian struktur mikro pada daerah HAZ dan Las. Pada setiap penggunaan variasi arus pengelasan mempunyai perbedaan struktur ferit dan austenite yang halus serta kasar, karena struktur yang terbentuk pada proses pengelasan terjadi karena adanya transformasi panas pada benda uji (Callister, 2006).

Pada Tabel 2 terlihat bahwa perbedaan struktur mikro pada daerah HAZ menunjukkan pengelasan dengan variasi arus $60 \mathrm{~A}$ memiliki struktur mikro ferit dan austenite, kedua fase tersebut terlihat sama-sama dominan. Pada arus 70 A hasil struktur mikronya berupa ferit dan austenite, namun terlihat fase austenite warnanya lebih terang dibanding penggunaan arus $60 \mathrm{~A}$. pengelasan menggunakan arus $60 \mathrm{~A}$ tidak begitu baik untuk mencairkan logam tambahan (filler) karena panas yang masuk kurang, terlihat dari besar butiran pada daerah pemgelasan dengan daerah HAZ tidak terlalu luas (Saripudin, 2013).

Tabel 2. Perbandingan hasil struktur mikro daerah HAZ dan Las.

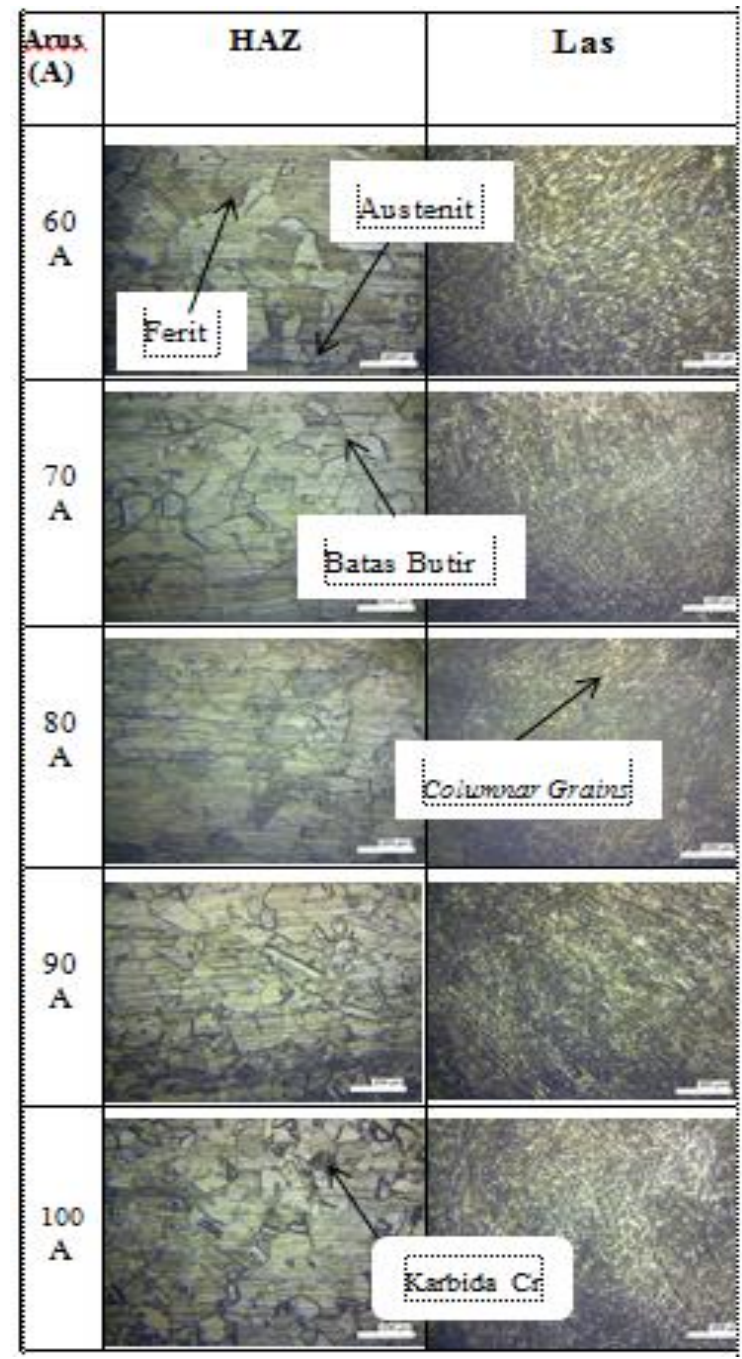

Pada arus 80 A terlihat adanya struktur ferit dan austenit, namun struktur austenit lebih dominan dan warna ferit lebih gelap dibanding pada penggunaan arus $70 \mathrm{~A}$. Sedangkan pada arus 90 A mempunyai struktur yang sama seperti pada penggunaan arus $80 \mathrm{~A}$, namun pada arus 90 A warna feritnya memudar. Menurut penelitian yang dilakukan Widyatmoko (2017) bahwa semakin besar penggunaan variasi arus pada saat pengelasan maka butiran struktur berubah menjadi kasar yang mengakibatkan kekuatan pada daerah HAZ menjadi rendah.

Penggunaan arus 100 A struktur mikronya berupa ferit dan Austenite, namun lebih di dominasi fase Austenite. Selain itu, terdapat kandungan karbida $\mathrm{Cr}$. adanya karbida $\mathrm{Cr}$ disebabkan krom dan karbida yang terlarut/mengendap karena adanya panas yang berlebih (Ojahan dkk., 2017). 
Perbedaan pada arus 60 A, 70 A, 80 A, 90 A dan 100 A adalah pada setiap penambahan arus membuat struktur mikro di daerah HAZ berkembang dan butirnya bertambah kasar. Untuk daerah las pada semua penggunaan arus pengelasan terlihat bentuk butirnya sama, yakni berbentuk columnar grains (berbutir memanjang).

\section{Hasil Uji Tarik}

Pengujian tarik menggunakan standart ASTM E8/E8M-09 dengan Luas Area penampang $9 \mathrm{~mm}^{2}$. Hasil pengujian tarik ratarata terlihat pada Gambar 6 .

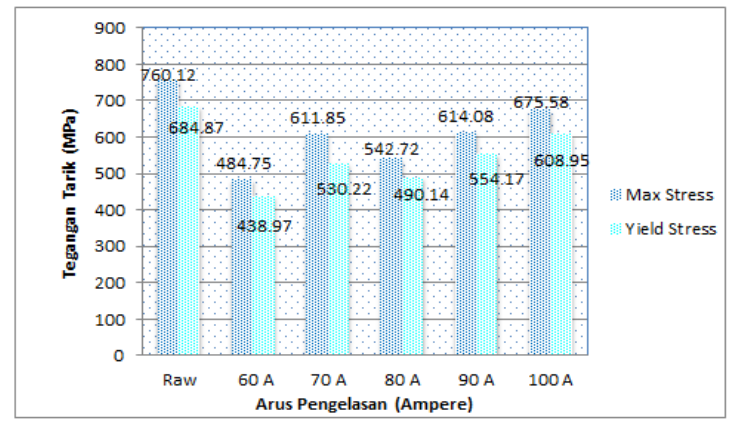

\section{Gambar 6. Grafik hubungan kekuatan tarik dengan arus pengelasan.}

Gambar 6 menunjukkan bahwa hasil tegangan tarik paling tinggi pada penggunaan arus 100 A dengan nilai $608,95 \mathrm{MPa}$, sedangkan tegangan tarik terendah $438,97 \mathrm{MPa}$ terletak pada penggunaan arus $60 \mathrm{~A}$. Tegangan tarik maksimal tertinggi $675,56 \mathrm{MPa}$ juga terdapat pada pengelasan dengan arus 100 A. Pada setiap penambahan arus pengelasan, maka kekuatan tarik pada material yang dilas juga akan meningkat (Parekke, 2014).

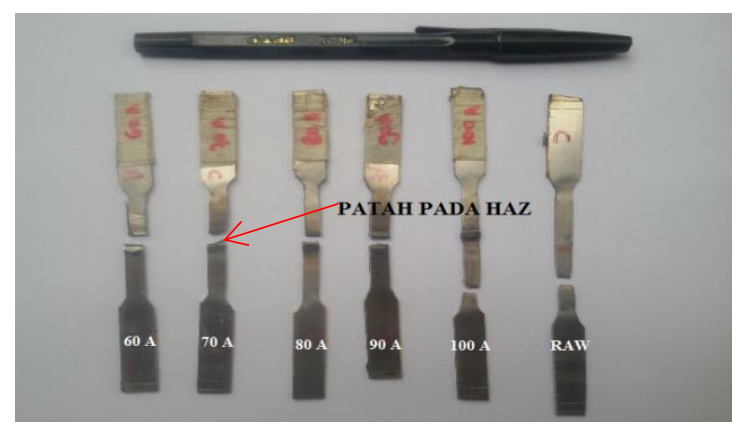

Gambar 7. Spesimen hasil uji tarik
Hasil pengujian tarik menunjukkan bahwa kekuatan tarik rata-rata raw material lebih tinggi jika dibandingkan dengan kekuatan tarik material yang dilakukan pengelasan dengan berbagai variasi arus. Menurut Yunus dan Nofri (2013), baja tahan karat merupakan material baja paduan tinggi, yang kualitas sambungannya akan menjadi getas karena pengaruh panas dari pengelasan.

Gambar 7 memperlihatkan bahwa ratarata patahan hasil pengujian tarik terjadi pada daerah HAZ. Hal ini dikarenakan panas yang masuk saat pengelasan membuat struktur mikro di daerah HAZ mengalami pemuaian sehingga membuat struktur mikronya menjadi kasar. Menurut penelitian yang dilakukan oleh Azwinur dkk. (2017) bahwa penggunaan arus yang besar akan menyebabkan daerah HAZ membuat pengaruh re-kristalisasi. Dimana rekristalisasi menyebabkan terjadinya butir-butir pada daerah HAZ semakin bertambah besar, dan butiran-butiran tersebut akan menurunkan kekuatan mekanis suatu material.

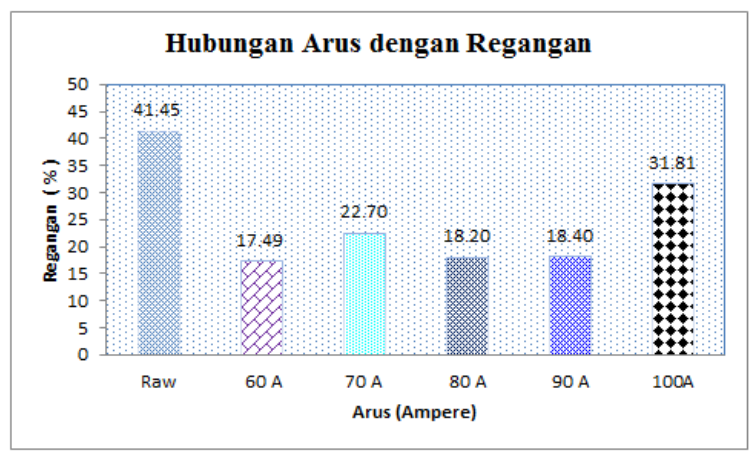

\section{Gambar 8. Grafik hubungan regangan dengan arus pengelasan.}

Gambar 8 menunjukkan bahwa hasil regangan yang paling tinggi adalah 31,81\% pada pengelasan arus $100 \mathrm{~A}$. Sedangkan nilai terendah sebesar $17,49 \%$ pada pengelasan dengan arus $60 \mathrm{~A}$. Hal ini karena panas yang dihasilkan arus 60 A terlalu kecil untuk mencairkan elektroda tungsten dan kawat las terhadap logam induk, sehingga menyebabkan sambungan las tidak cukup kuat. Menurut penelitian yang dilakukan Nasrul dkk., (2011) bahwa hubungan antara struktur mikro dengan kekuatan tarik pada logam dimana semakin besar butiran logam yang dihasilkan maka akan membuat kekuatan luluhnya semakin rendah. 
Pengujian kekerasan dilakukan pada daerah logam induk, HAZ dan Las. Hasil pengujian rata-rata kekerasan Rockwell (HRB) ditunjukkan pada Gambar 9.

Gambar 9 menunjukkan bahwa kekerasan di daerah HAZ paling tinggi adalah pada arus 60 A dengan nilai kekerasan $72,75 \mathrm{HRB}$, dan yang paling rendah $60,75 \mathrm{HRB}$ pada penggunaan arus 100 A. Dalam Gambar 9 terlihat bahwa rata-rata pada setiap penambahan arus terjadi penurunan kekerasan di daerah HAZ, hal ini dikarenakan panas yang masuk saat proses pengelasan dapat memperbesar butir (pemuaian) dan struktur logamnya berubah menjadi kasar (Sonawan, 2004). Dimana kekasaran butir dapat menurunkan sifat kekerasan pada suatu material. Nilai kekerasan tertinggi pada daerah las terletak pada penggunaan kuat arus $100 \mathrm{~A}$ dengan nilai 88 HRB dan paling rendah adalah pada penggunaan kuat arus 80 A dengan nilai 84,25 HRB.

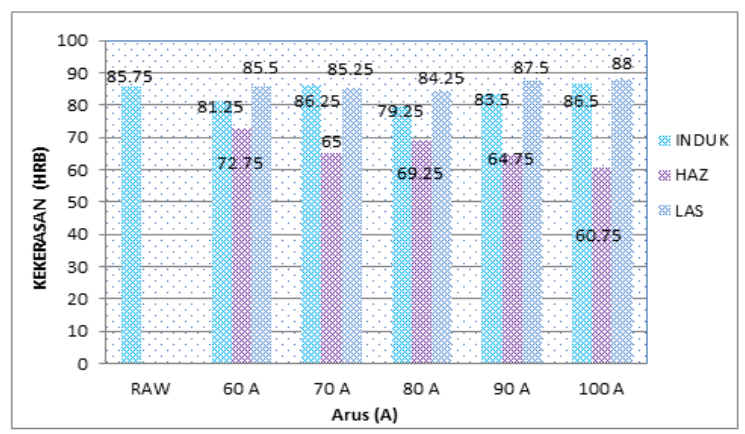

\section{Gambar 9. Grafik hasil uji kekerasan}

Gambar 9 menunjukkan rata-rata nilai kekerasan pada daerah las lebih tinggi dibandingkan nilai kekerasan di daerah $\mathrm{HAZ}$ dan logam induk, hal ini karena masukan panas (heat input) pengelasan yang tinggi maka butir yang dibawa akan semakin halus. Sehingga ketika butir memadat logam pengelasan akan berkaitan secara kuat yang menyebabkan kekerasan yang tinggi di daerah las (Widodo, 2016).

\section{KESIMPULAN}

1. Dari pengujian foto makro terlihat hasil pengelasan yang paling bagus adalah pada pengelasan dengan arus $100 \mathrm{~A}$, sedangkan pengelasan yang menggunakan variasi arus 60 A bahan tambahannya tidak mencair secara sempurna sehingga sambungan las tidak dapat menyatu secara bagus pada logam induk.
Hasil pengujian struktur mikro pada semua variasi arus menghasilkan struktur yang sama, yakni ferit dan austenite. Namun pada arus $100 \mathrm{~A}$ terdapat kandungan karbida $\mathrm{Cr}$ yang mengembang.

2. Hasil pengujian tarik tertinggi terletak pada penggunaan arus 100 A dengan nilai 608,95 MPa. Sedangkan nilai kekuatan tarik terendah pada arus 60 A dengan nilai 438,97 MPa. Tegangan tarik maksimum tertinggi $675,58 \mathrm{MPa}$ juga terletak pada penggunaan arus $100 \mathrm{~A}$.

3. Hasil nilai kekerasan pada daerah HAZ yang paling tinggi adalah 72,75 HRB terjadi pada penggunaan arus 60 A. Sedangkan kekerasan daerah $\mathrm{HAZ}$ yang paling rendah adalah pada arus 100 A dengan nilai 60,75 HRB.

Nilai kekerasan di daerah las tertinggi adalah 88 HRB terletak pada arus $100 \mathrm{~A}$, sedangkan daerah las dengan nilai terendah terletak pada arus 80 A dengan nilai 84,25 HRB.

\section{DAFTAR PUSTAKA}

Alip, M., 1989, Teori dan Praktik las, Departemen Pendidikan dan Kebudayaan.

Callister, J. \& William, D., 2006, Seventh Edition Materials Science And Engineering, Department og Mettalurgical Engineering The University of Utah, USA.

Nasrul, Y., Suryanto, H., \& Abdul Qolik., 2016, Pengaruh Variasi Arus Las Terhadap Kekerasan dan Kekuatan Tarik Sambungan Dissimilar Stainless Steel 304 dan ST 37, Jurnal Teknik Mesin Vol 24, Universitas Negeri Malang, Malang.

Ojahan, T., Hendronursito, Y., \& Daniel A.S., 2017, Analisis Pengaruh Parameter Pengelasan GTAW Stainless Steel AISI 304 Terhadap Sifat Mekanis dan Struktur Mikro, POROS Vol. 15 Nomor 1, Universitas Mahalayati, Lampung.

Parekke, S., 2014, Pengaruh Pengelasan Logam Berbeda (AISI 1045) Dengan (AISI 316L) Terhadap Sifat Mekanis dan Struktur Mikro, Jurnal Sains \& Teknologi, Vol.3 No.2, Universitas Hasanuddin.

Sonawan, H., 2004, Pengantar Untuk Memahami Proses Pengelasan Logam, Alfabeta, Bandung.

Widodo, R., \& Suheini, 2016, Pengaruh kuat arus listrik dan jenis kampuh las terhadap kekerasan dan struktur makro pada 
pengelasan stainless steel AISI 304, Jurnal IPTEK, Vol. 20 No. 02, Institut Teknologi Adhi Tama, Surabaya.

Yunus, Y. \& Nofri, 2013, Variasi Arus Listrik Terhadap Sifat Mekanik Mikro Sambungan Las Baja Tahan Karat AISI 304, E-Journal Widya Eksata. 1 (1). 